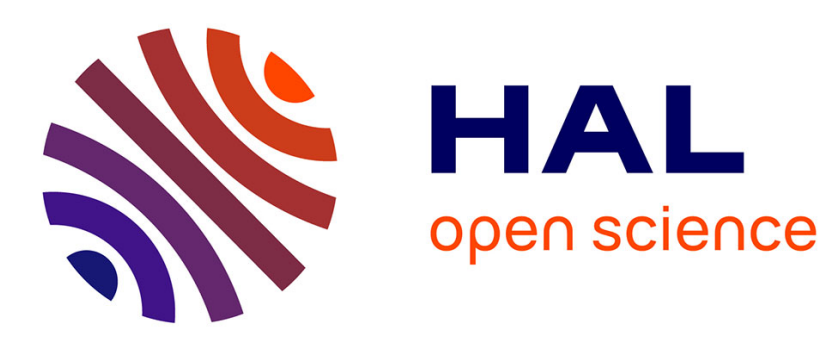

\title{
Catalytic Reduction of Oxygen by a Copper Thiosemicarbazone Complex
}

Tatiana Straistari, Adina Morozan, Sergiu Shova, Marius Reglier, Maylis Orio, Vincent Artero

\section{- To cite this version:}

Tatiana Straistari, Adina Morozan, Sergiu Shova, Marius Reglier, Maylis Orio, et al.. Catalytic Reduction of Oxygen by a Copper Thiosemicarbazone Complex. European Journal of Inorganic Chemistry, 2020, 2020 (48), pp.4549-4555. 10.1002/ejic.202000869 . hal-03028649

\section{HAL Id: hal-03028649 https://hal.science/hal-03028649}

Submitted on 4 Jan 2022

HAL is a multi-disciplinary open access archive for the deposit and dissemination of scientific research documents, whether they are published or not. The documents may come from teaching and research institutions in France or abroad, or from public or private research centers.
L'archive ouverte pluridisciplinaire HAL, est destinée au dépôt et à la diffusion de documents scientifiques de niveau recherche, publiés ou non, émanant des établissements d'enseignement et de recherche français ou étrangers, des laboratoires publics ou privés. 


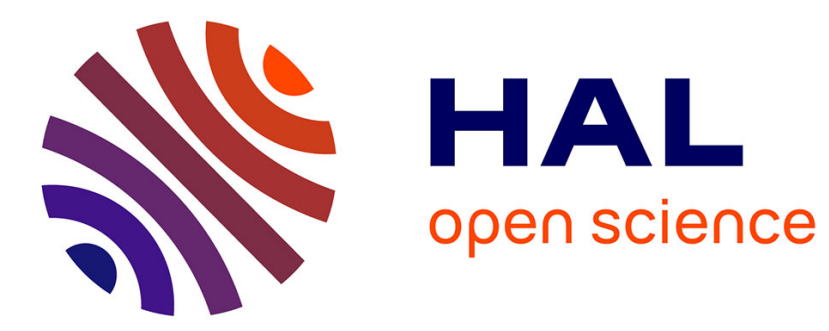

\section{Catalytic Reduction of Oxygen by a Copper Thiosemicarbazone Complex}

Tatiana Straistari, Adina Morozan, Sergiu Shova, Marius Réglier, Maylis Orio, Vincent Artero

\section{To cite this version:}

Tatiana Straistari, Adina Morozan, Sergiu Shova, Marius Réglier, Maylis Orio, et al.. Catalytic Reduction of Oxygen by a Copper Thiosemicarbazone Complex. European Journal of Inorganic Chemistry, Wiley-VCH Verlag, 2020, 2020 (48), pp.4549-4555. 10.1002/ejic.202000869 . hal-03179025v2

\section{HAL Id: hal-03179025 \\ https: / hal.archives-ouvertes.fr/hal-03179025v2}

Submitted on 10 May 2021

HAL is a multi-disciplinary open access archive for the deposit and dissemination of scientific research documents, whether they are published or not. The documents may come from teaching and research institutions in France or abroad, or from public or private research centers.
L'archive ouverte pluridisciplinaire HAL, est destinée au dépôt et à la diffusion de documents scientifiques de niveau recherche, publiés ou non, émanant des établissements d'enseignement et de recherche français ou étrangers, des laboratoires publics ou privés. 


\title{
Catalytic reduction of oxygen by copper thiosemicarbazone complex
}

\author{
Tatiana Straistari, ${ }^{[a, b, c]}$ Adina Morozan, ${ }^{*[a]}$ Sergiu Shova, ${ }^{[d]}$ Marius Réglier,${ }^{[b]}$ Maylis Orio ${ }^{*[b]}$ and Vincent \\ Artero $^{[\mathrm{a}]}$ \\ [a] Dr. T. Straistari, Dr, A. Morozan*, Dr. V. Artero \\ Laboratoire de Chimie et Biologie des Métaux \\ Université Grenoble Alpes, CNRS, CEA/IRIG \\ 17 rue des Martyrs, F-38054 Grenoble cedex 9, France \\ E-mail: adina.morozan@cea.fr \\ [b] Dr. T. Straistari, Dr. M. Réglier, Dr. M. Orio* \\ Aix Marseille Univ, CNRS, Centrale Marseille, iSm2, Marseille, France. \\ E-mail: maylis.orio@univ-amu.fr \\ [c] Dr. T. Straistari \\ Institute of Chemistry \\ Academy of Sciences of Moldova \\ 3, Academiei street, Chisinau MD 2028, Republic of Moldova \\ [d] Dr. S. Shova \\ Institute of Macromolecular Chemistry "Petru Poni" \\ 41A Grigore Ghica Voda Alley, lasi 700487, Romania \\ Supporting information for this article is given via a link at the end of the document
}

\begin{abstract}
The new copper(II) thiosemicarbazone complex CuL $\left(\mathrm{H}_{2} \mathrm{~L}\right.$ $=4-\{$ bis (4-(p-methoxyphenyl)-thiosemicarbazone $)\}-2,3-$ butane $)$ was synthesized and structurally characterized. Its electrochemical behavior in $\mathrm{N}, \mathrm{N}$-dimethylformamide (DMF) was examined. This complex proved active for homogeneous oxygen reduction reaction (ORR) in DMF in the presence of organic acids. The activity and selectivity for ORR was found to be dependent on the nature of the proton source (phenol or acetic acid). This study both confirmed the previously reported free energy linear correlation between selectivity and overpotential requirement [Passard et al., J. Am. Chem. Soc. 2016, 138, 2925-2928] and suggests that additional descriptors are required for a full understanding of the catalytic ORR behavior.
\end{abstract}

\section{Introduction}

Developing efficient and selective catalysts for the oxygen reduction reaction (ORR) is key for the development of fuel cell technologies. Current proton-exchange membrane fuel cells (PEMFCs) contain platinum as the cathode ORR catalyst, despite their quite large $(400 \mathrm{mV})$ overpotential requirement for ORR. Yet, a global economy based on $\mathrm{H}_{2}$ /air PEMFCs cannot be sustained by the worldwide mining of noble metals. ${ }^{[1]}$ In Nature, ORR is known to occur at competitive overpotentials. ${ }^{[2]}$ Two groups of Cu-based enzymes exhibit good performances as catalysts for the selective reduction process of oxygen to water: (i) cytochrome $c$ oxidases ( $\mathrm{CCOs}$ ) exhibit a bimetallic active site consisting of an iron porphyrin heme a3 and a tris-histidinecoordinated $\mathrm{Cu}\left(\mathrm{Fe}_{a 3} / \mathrm{C}_{B}\right) ; ;^{[2-3]}$ (ii) multicopper oxidases (MCOs) such as laccase and bilirubin oxidase, contain at least one mono-nuclear site containing one type-1 (T1) Cu' or blue copper, a trinuclear site containing one type-2 (T2) $\mathrm{Cu}^{\prime}$ or normal copper, and two type-3 (T3) $\mathrm{Cu}^{\prime}$ or coupled binuclear copper. ${ }^{[4-5]}$ These actives sites are inspirations for the design of alternative homogeneous and heterogeneous cooper-based ORR catalysts. A number of cooper-based molecular structures have already been reported for proton-assisted catalytic reduction of oxygen. ${ }^{[6-16]}$

We describe here the synthesis of a new copper(II) thiosemicarbazone complex (CuL, Scheme 1) and report on its homogeneous catalytic ORR activity in N,N-dimethylformamide (DMF) in the presence of various acids of different strength (phenol - $\mathrm{PhOH}$, acetic acid - $\mathrm{AcOH}$ and trifluoroacetic acid TFA) used as proton source.

\section{Results and Discussion}

\section{Synthesis and characterization}

The red copper(II) thiosemicarbazone complex CuL (Figure 1) was obtained from the reaction of 4 -\{bis(4-(p-methoxyphenyl)thiosemicarbazone)\}-2,3-butane $\left(\mathbf{H}_{2} \mathbf{L}\right)$ ligand ${ }^{[17]}$ and copper(II) nitrate in methanol with a yield of $70 \%$. Complexation of the $\mathrm{L}^{2-}$ ligand is indicated in the IR spectrum by a shift of the $v_{\mathrm{C}=\mathrm{N}}$ band from $1593 \mathrm{~cm}^{-1}$ in $\mathbf{H}_{2} \mathrm{~L}^{[17]}$ to $1598 \mathrm{~cm}^{-1}$ in CuL. In addition, thione-thiol tautomerism ${ }^{[18-19]}$ follows complexation as indicated by the disappearance of the $\bar{v}_{\mathrm{C}=\mathrm{S}}$ band at $829 \mathrm{~cm}^{-1}$ which is replaced by a new $\bar{v}_{\mathrm{C}-\mathrm{S}}$ band at $821 \mathrm{~cm}^{-1}$ in the spectra of CuL complex. ${ }^{[17]}$

The crystal structure (Figure 1) reveals that the ligand adopts an s-cis (synperiplanar) conformation of the substituents within the butane unity upon complexation. The $\mathrm{Cu}$ ion is four-coordinated and sits by $0.039 \AA$ out of $\mathrm{N}_{2} \mathrm{~S}_{2}$ plane. The three five-membered chelate rings Cu1N3C9C11N4, Cu1N3N2C8S1 and Cu1N4N5C13S2 are also essentially planar with mean plane deviation of $\mathrm{Cu}$ coordination center of $0.006(2), 0.027(1)$ and $0.036(1) \AA$, respectively. The angles between the coordinate plane and the two phenyl rings $\mathrm{C} 2 \mathrm{C} 3 \mathrm{C} 4 \mathrm{C} 5 \mathrm{C} 6 \mathrm{C} 7$ and $\mathrm{C} 14 \mathrm{C} 15 \mathrm{C} 16 \mathrm{C} 17 \mathrm{C} 18 \mathrm{C} 19$ are of $27.1(1)^{\circ}$ and $4.8(1)^{\circ}$, respectively.

The ligand is in the thiolate form which is evidenced by the increase of the C1-S8 and C13-S2 bond distances (1.762(4) $\AA$ and $1.751(5) \AA$, respectively) compared to those observed for 
the neutral ligand $\mathrm{H}_{2} \mathrm{~L}\left(1.674 \AA\right.$ and $1.673 \AA$, respectively). ${ }^{[17]}$ Electronic absorption spectrum recorded in DMF for the CuL neutral complex exhibits two intense bands at $\lambda_{\max }=405$ and $483 \mathrm{~nm}$ (Figure 2b, black line).

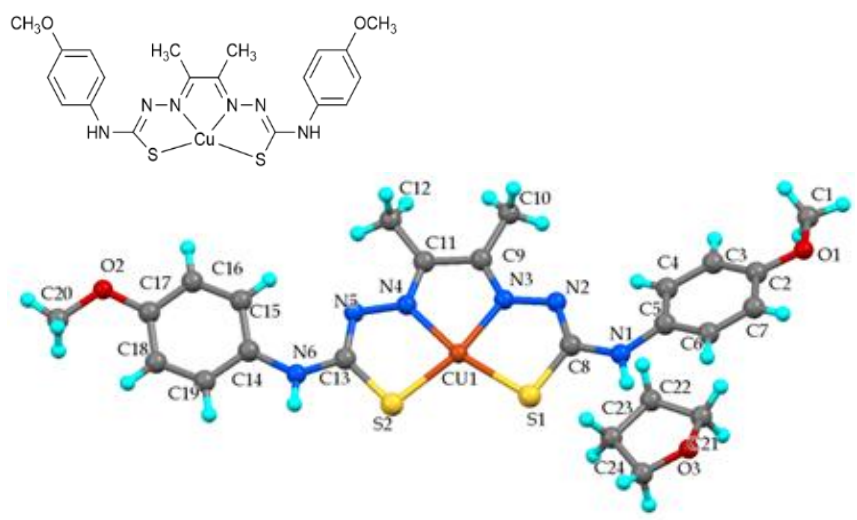

Figure 1. Molecular and X-ray crystal structures of [CuL]·THF with atom labelling scheme and ellipsoids parameters at $50 \%$ probability level. Selected bond lengths: $\mathrm{Cu}(1)-\mathrm{S}(1) 2.2170(14) \AA, \mathrm{Cu}(1)-\mathrm{S}(2) 2.2145(12) \AA, \mathrm{Cu}(1)-\mathrm{N}(3)$ $1.950(3) \AA, \mathrm{Cu}(1)-\mathrm{N}(4) 1.944(4) \AA$. Selected bond angles: $\mathrm{S}(2)-\mathrm{Cu}(1)-\mathrm{S}(1)$ $107.77(5)^{\circ}, \mathrm{N}(3)-\mathrm{Cu}(1)-\mathrm{S}(1) 85.91(13)^{\circ}, \mathrm{N}(3)-\mathrm{Cu}(1)-\mathrm{S}(2) 165.70(13)^{\circ}, \mathrm{N}(4)-$ $\mathrm{Cu}(1)-\mathrm{S}(1) 167.09(10)^{\circ}, \mathrm{N}(4)-\mathrm{Cu}(1)-\mathrm{S}(2) 85.07(10)^{\circ}$ and $\mathrm{N}(4)-\mathrm{Cu}(1)-\mathrm{N}(3)$ $81.19(15)^{\circ}$

\section{Electrochemical characterization}

The cyclic voltammograms of CuL complex (Figure 2a and Figure $\mathrm{S} 1-\mathrm{a}$ ) recorded in DMF over the potential range from -1.5 $\mathrm{V}$ to $0.7 \mathrm{~V}$ vs NHE exhibit only one electrochemically reversible process observed at $\mathrm{E}_{1 / 2}=-0.48 \mathrm{~V}$ vs $\mathrm{NHE}$ (where $E_{1 / 2}=\left[E_{p c}+\right.$ $\left.E_{p a}\right] / 2$ ) corresponding to the $\mathrm{Cu}^{\prime \prime} / \mathrm{Cu}^{\prime}$ redox couple. The peak current $\left(i_{p}\right)$ varies linearly with the square root of the scan rate $\left(v^{1 / 2}\right)$, indicating a diffusion-controlled process (Figure S1-b). Spectro-electrochemical measurements performed at $=-0.55 \mathrm{~V}$ vs NHE show a uniform decrease of the absorption profile with the concomitant formation of a new absorption band at $361 \mathrm{~nm}$ when $\mathrm{CuL}$ is reduced. The reduction process proceeds smoothly with an isosbestic point at $396 \mathrm{~nm}$. Reoxidation at $+0.01 \mathrm{~V}$ leads to an UV-vis spectrum (Figure $2 b$, red line) similar to the initial one (Figure $2 b$, black line), confirming the full reversibility of the one-electron electrochemical process observed at $-0.48 \mathrm{~V} v \mathrm{v}$ NHE.

\section{Theoretical calculations}

In an effort to understand the redox behavior of CuL, DFT calculations were undertaken and the structure of the complex was subjected to geometry optimization. DFT calculations show that the $\mathrm{Cu}-\mathrm{S}$ and $\mathrm{Cu}-\mathrm{N}$ bond lengths for the computed structure are comparable to those determined by $\mathrm{X}$-ray crystallography which confirms the presence of a $\mathrm{Cu}^{\text {II }}$ center in CuL ([Cu"L] $]^{0}, S=1 / 2$, Table S2 and Figure S2). Geometry optimization was also conducted on the one-electron reduced $\mathrm{CuL}^{-}$species. The resulting structure shows an elongation of both the $\mathrm{Cu}-\mathrm{N}$ and $\mathrm{Cu}-\mathrm{S}$ bond lengths consistently with a metalbased reduction process and the formation of a $\mathrm{Cu}(\mathrm{I})$ diamagnetic species $\left(\left[\mathrm{Cu} \mathbf{L}^{\prime}\right]^{-}, S=0\right)$. These theoretical results support that the observed redox process is assigned to the $\mathrm{Cu}^{\prime \prime} / \mathrm{Cu}$ ' couple.
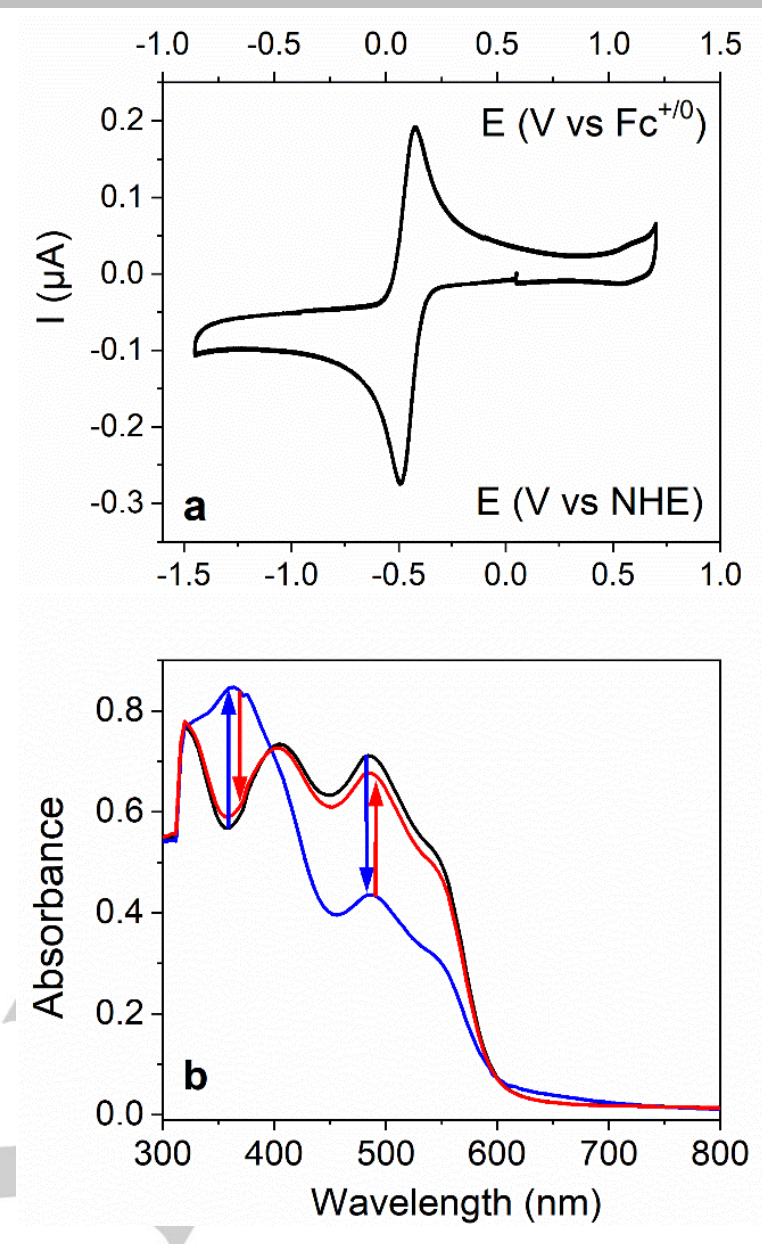

Figure 2. a). Cyclic voltammogram of CuL $(1 \mathrm{mM})$ recorded under Arsaturated DMF $\left(0.1 \mathrm{M}^{\mathrm{n}} \mathrm{Bu}_{4} \mathrm{NPF}_{6}\right)$, on GC electrode $(\varnothing 1.6 \mathrm{~mm})$, scan rate 100 $\left.\mathrm{mV} \cdot \mathrm{s}^{-1} ; \mathrm{b}\right)$. Electronic absorption spectra for the neutral CuL (black line), oneelectron-reduced species $\mathrm{CuL}^{-}$(blue line) and electrochemically re-oxidized CuL (red line).

$$
\operatorname{CuL}\left([\mathrm{Cu} " L]^{0} \mathrm{~S}=1 / 2\right)
$$

$$
\text { CuL- ([Cu'L]- } S=0)
$$

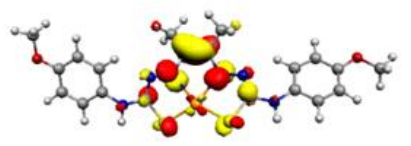

LUMO
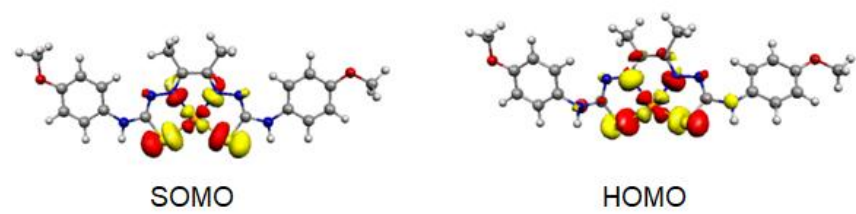

Figure 3. DFT-calculated redox-active orbitals for $\mathrm{CuL}$ and $\mathrm{CuL}^{-}$.

The DFT-calculated electronic structure of CuL leads to a Single Occupied Molecular Orbital (SOMO) for the neutral species that is mainly distributed on the metal center (44\%) with nonnegligible contributions from the coordinating atoms (30\%, Satoms and $25 \%, \mathrm{~N}$-atoms) which is typical for a mononuclear $\mathrm{Cu}^{\text {II }}$ complex in a square planar geometry (Figure S3). In the one-electron reduced species, the Highest Occupied Molecular Orbital (HOMO) is also distributed over the metal and the first 
coordination sphere, which is the proof of a metal-centred reduction process (Figure 3 ). Redox potential calculations were also conducted to assign the electrochemical event in CuL (Table S3). The computed values for the one-electron reduction process leading to $\mathrm{CuL}^{-}$is of -0.55 vs NHE. The computed potential value is in fair agreement with the experimental data and thus support the assignment of the reduction loci in the complex.

\section{Catalytic $\mathrm{O}_{2}$ reduction activity}

The cyclic voltammogram of CuL (black traces, Figures 4, a-c) was significantly modified when $\mathrm{O}_{2}$ is bubbled into the DMF solution (blue traces, Figure 4, a-c): A slight increase in the cathodic current is observed while the backward anodic peak is disappeared. This behavior indicates that the CuL complex react with $\mathrm{O}_{2}$ following one-electron reduction of the copper core.

Addition of phenol $(\mathrm{PhOH}, \mathrm{pKa}=1.8)^{[20]}$ or acetic acid $(\mathrm{AcOH}$, $\mathrm{pKa}=13.3)^{[21]}$ to the $\mathrm{O}_{2}$-saturated solutions triggers the appearance of catalytic waves with mid-wave potentials similar to that of the $\mathrm{Cu}^{\prime \prime} / \mathrm{Cu}^{\prime}$ couple (Figures 4, a and b). Such a catalytic wave likely corresponds to ORR and was not observed in the absence of the CuL complex (Figure 4, a and b, dashed curves). The catalytic response depends on the strength and the concentration (Figure S4 and Figure S5) of the acid, the catalytic wave appears better defined when $\mathrm{AcOH}$ was added as a proton source. The addition of trifluoroacetic acid (TFA, pKa $=6)^{[21]}$ as proton source leads to a different behavior. An irreversible reduction peak appears at $-0.16 \mathrm{~V}$ (Figure 4c, Figure S6). The identical presence of this peak, both in the absence and presence of oxygen, indicates protonation of the CuL complex (Figure S7). In the presence of TFA, the same ORR signal is observed both in the presence and absence of CuL (Figure 4c), suggesting that CuL does not act as a catalyst for the ORR in the presence of TFA.

As specific for electrochemical processes, the energy-efficiency of the ORR depends on the driving force required for the reaction to proceed at a significant rate. This driving force is quantified as the overpotential, defined as the difference between the applied potential to drive the ORR and the thermodynamic equilibrium potential of the ORR. The standard potential of ORR to form $\mathrm{H}_{2} \mathrm{O}$ in DMF and in the presence of an acid as proton source (denoted as $\mathrm{HA}$ ), expressed by equation (2) according to previous calculations, ${ }^{[22-23]}$ was reported in Table 1 for the conditions considered in this study.

$E_{O_{2} / H_{2} O, H A, D M F}^{0}=0.799-\frac{R T \ln 10}{F} p K_{a, H A, D M F}$

An accurate benchmarking of the performances of the homogeneous ORR catalysts should involve the construction of a catalytic Tafel plot. ${ }^{[24-25]}$ However, the required methodology to collect accurate kinetic data for such 4-electron $\mathrm{O}_{2}$ reduction process to $\mathrm{H}_{2} \mathrm{O}$ involving two distinct reactants is still incomplete. Instead, the overpotential requirement (denoted $\Delta E^{O R R}$, Table 1) to drive ORR can provide the basis for a relevant analysis of the homogeneous ORR catalysts. $\Delta E^{O R R}$ is expressed as the difference between the standard potential of ORR $\left(E_{\mathrm{O}_{2} / \mathrm{H}_{2} \mathrm{O}, \mathrm{HA}, \mathrm{DMF}}^{\mathrm{N}}\right)$ and the half-wave potential of the ORR catalytic wave (denoted $E_{\text {cat } / 2}^{O R R}$, equation (3)) under the conditions used for the measurement.

$\Delta E^{O R R}=E_{O_{2} / H_{2} O, H A, D M F}^{0}-E_{c a t / 2}^{O R R}$
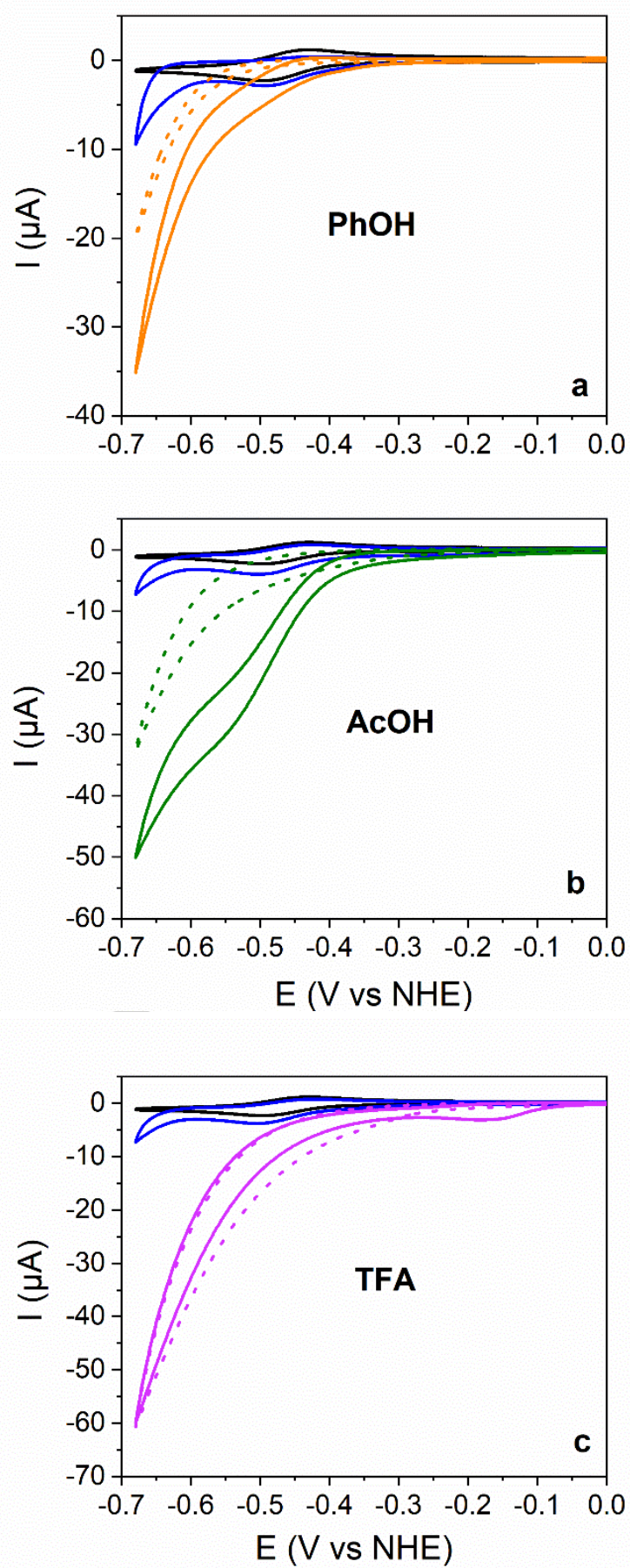

Figure 4. Cyclic voltammograms for CuL (1 M) in DMF (0.1 M nBu4NPF6) on GC electrode (ø $5 \mathrm{~mm}$ ), scan rate $100 \mathrm{mV} \cdot \mathrm{s}^{-1}$, under Ar-saturated atmosphere (black curves), $\mathrm{O}_{2}$-saturated atmosphere (blue curves) and $\mathrm{O}_{2}$-saturated atmosphere with the addition of: a). $\mathrm{PhOH}$ (50 mM, orange curves), b). $\mathrm{AcOH}$ (50 mM, green curves), c). TFA (50 mM, purple curves). The CVs of acids recorded under $\mathrm{O}_{2}$-saturated atmosphere in the absence of $\mathrm{CuL}$ are shown in dashed lines with the same color for comparison.

Table 1 summarizes the experimental $\Delta E^{O R R}$ values for CuL in DMF as function of the strength $\left(\mathrm{pK}_{\mathrm{a}}\right)$ of acids. 
Table 1. $\mathrm{pK}_{\mathrm{a}}$ of different acids and main parameters for the ORR with CuL in DMF

\begin{tabular}{lllll}
\hline Acid & $\mathrm{pK}_{\mathrm{a}, \mathrm{HA}}$ & $\begin{array}{l}E_{\mathrm{O}_{2} / \mathrm{H}_{2} O, H A, D M F}^{0} \\
(\mathrm{~V} \text { vs NHE) }\end{array}$ & $\begin{array}{c}E_{\text {cat } / 2}^{\text {ORR }} \\
(\mathrm{V} \text { vs NHE) }\end{array}$ & $\begin{array}{c}\Delta E^{\text {ORR }} \\
(\mathrm{V} \text { vs NHE) }\end{array}$ \\
\hline $\mathrm{PhOH}$ & $18.8^{[20]}$ & -0.329 & -0.495 & 0.166 \\
$\mathrm{AcOH}$ & $13.3^{[21]}$ & -0.010 & -0.480 & 0.490 \\
\hline
\end{tabular}

Rotating ring-disk electrode (RRDE) voltammograms were recorded in DFM with CuL in solution for quantifying the production of $\mathrm{H}_{2} \mathrm{O}_{2}$ in the presence of $\mathrm{PhOH}$ and $\mathrm{AcOH}$ under electrochemical conditions and estimating $\mathrm{CuL}$ selectivity for 2electron vs 4-electron $\mathrm{O}_{2}$ reduction. The potential at the $\mathrm{GC}$ disk was scanned through the catalytic region (from $-0.2 \mathrm{~V}$ to $-0.6 \mathrm{~V}$ vs $\mathrm{NHE}$ ) and the potential at the Pt ring was fixed at $1.07 \mathrm{~V}$ vs $\mathrm{NHE}$ in order to detect the oxidation of the ORR-generated hydrogen peroxide. Figure 5 presents typical RRDE voltammograms showing the ring and disk currents obtained from ORR. ORR catalytic currents were observed at the disk, in accordance with previously discussed CVs measurements (Figure 4). The ring currents, which follow the shape of the disk currents (Figure 5), can be attributed to the oxidation of the species generated in the reduction processes at the disk, which can be either reduced forms of $\mathrm{CuL}$ and $\mathrm{H}_{2} \mathrm{O}_{2}$. In the control experiments performed in the presence of CuL without acid, the ring currents correspond only to the reoxidation of reduced forms of CuL. Thus, for a proper evaluation of the ORR process, $I_{\text {ring }}$ measured in the presence of acid has been corrected by substracting $I_{\text {ring }}$ measured without acid. Another series of control experiments was performed in the absence of CuL (Figure 5, dashed curves) and revealed that the $\mathrm{O}_{2}$-reduction process occurring directly at the GC disk is only observed in the presence of acids and at more negative potentials. Figure $5 \mathrm{c}$ shows the corresponding Faradaic efficiencies for $\mathrm{H}_{2} \mathrm{O}_{2}$ production mediated by CuL in DMF in the presence of acids in the explored potential window, obtained by application of equation (1) at $500 \mathrm{rpm}$. The Faradaic efficiencies for $\mathrm{H}_{2} \mathrm{O}_{2}$ production vary from $20 \%$ to $41 \%(\mathrm{PhOH})$ or from $37 \%$ to 59 $\%(\mathrm{AcOH})$ in the potential window from $-0.45 \mathrm{~V}$ to $-0.6 \mathrm{~V}$ (Figure $5 \mathrm{c})$. Data are summarized in Table S4. Nevertheless, CuL catalyzes the $\mathrm{O}_{2}$ reduction by a predominant $4 \mathrm{H}^{+} / 4 \mathrm{e}^{-}$and $2 \mathrm{H}^{+} / 2 \mathrm{e}^{-}$combined process in the presence of $\mathrm{PhOH}$ or $\mathrm{AcOH}$. A slight improved selectivity of $\mathrm{CuL}$ toward $\mathrm{H}_{2} \mathrm{O}$ production was observed with the weakest acid, $\mathrm{PhOH}$.

The selectivity for $\mathrm{H}_{2} \mathrm{O}$ production has been shown to depend on the thermodynamic standard potential, being controled by the $\mathrm{pK}_{\mathrm{a}}$ of the proton donor. ${ }^{[22]}$ Nocera and co-workers indeed showed for several molecular catalysts a correlation between the selectivity of catalyst for $\mathrm{H}_{2} \mathrm{O}$ production and the overpotential requirement for ORR. They showed that the ORR pathway to $\mathrm{H}_{2} \mathrm{O}$ production is favoured in the presence of stronger acid where there is a higher overpotential requirement for ORR. As a consequence, selectivity for $\mathrm{H}_{2} \mathrm{O}$ production was also found better for the same overpotential requirement when DMF is used as a solvent instead of acetonitrile because of greater activity of the proton in DMF. Our data are plotted in Figure 6, therefore modified from ref. ${ }^{[22]}$ When $\mathrm{PhOH}$ is used as the proton source, CuL behaves as other catalysts tested in DMF and displays selectivity closes to the one reported for the dicobalt $\left[\mathrm{Co}_{2}(\mathrm{OH})_{2} \mathrm{DPEN}\left(\mu-1,3-\mathrm{OC}(\mathrm{NH}) \mathrm{CH}_{3}\right)\right]^{3+} \quad(\mathrm{DPEN}=$ dipyridylethane naphthyridine) complex. The higher selectivity for $\mathrm{H}_{2} \mathrm{O}$ production is likely due to direct $\mathrm{O}_{2}$ reduction at the $\mathrm{GC}$ disk in the presence of $\mathrm{PhOH}$ for the determined overpotential
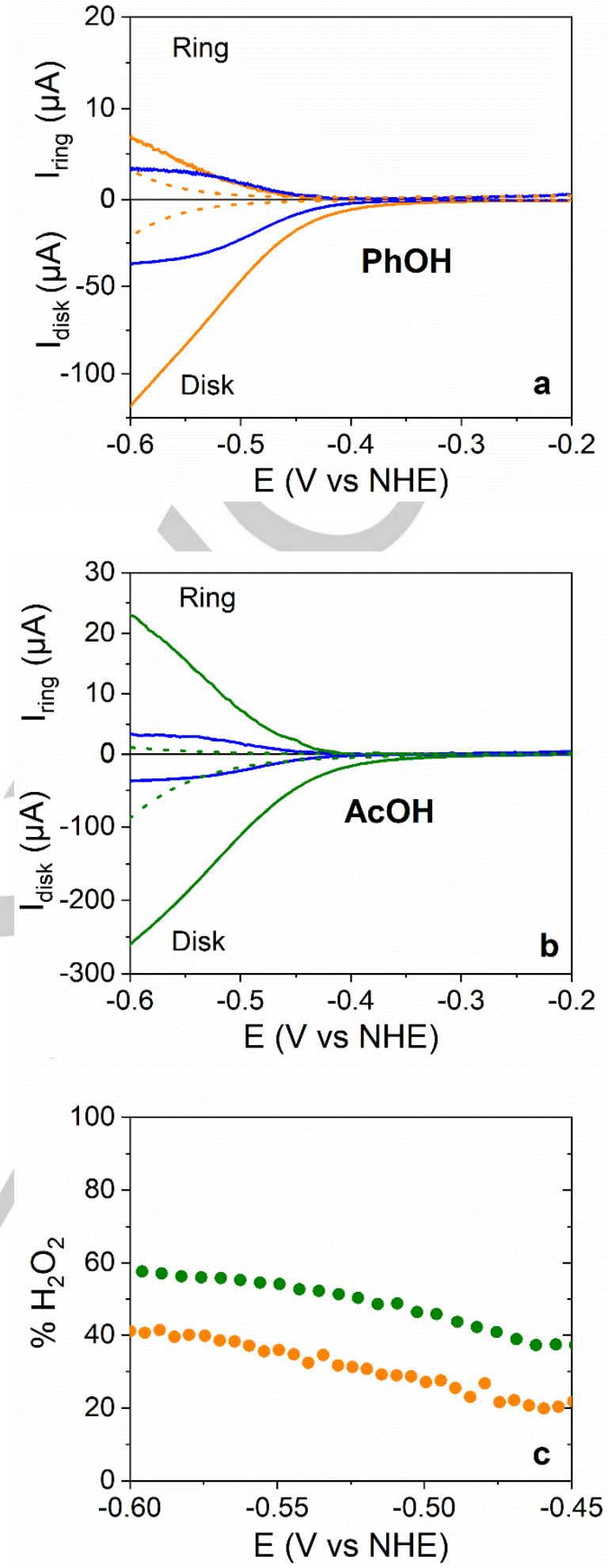

Figure 5. $(\mathrm{a}, \mathrm{b})$. Rotating ring-disk electrodes (RRDE) voltamogramms under $\mathrm{O}_{2}$-saturated atmosphere in DMF $\left(0.1 \mathrm{M}^{\mathrm{n}} \mathrm{Bu}_{4} \mathrm{NPF}_{6}\right.$ ) on $\mathrm{GC}$ electrode (ø 5 $\mathrm{mm}$ ), scan rate $10 \mathrm{mV} \cdot \mathrm{s}^{-1}, 500 \mathrm{rpm}$, ring current recorded with $\mathrm{Pt}$ ring held at $1.07 \mathrm{~V}$ vs NHE. All blue curves are for CuL (1 M), a). CuL (1 M) + PhOH (50 $\mathrm{mM}$, orange trace) and b). CuL $(1 \mathrm{M})+\mathrm{AcOH}(50 \mathrm{mM}$, green trace). The RRDE voltamograms of acids in the absence of $\mathrm{CuL}$ are shown as dashed line for comparison. In the orange and green plain curves, Iring has been corrected by substracting of the value measured without acid. (c). The RRDEdetermined $\%$ of produced $\mathrm{H}_{2} \mathrm{O}_{2}$ for reduction of one molecule of $\mathrm{O}_{2}$ vs applied potential for the two different acids (same color code).

requirement $\left(73 \% \mathrm{H}_{2} \mathrm{O}\right.$ for $\triangle E^{O R R}$ of $\left.0.166 \mathrm{~V}\right)$, but a more complex behavior is observed in the presence of $\mathrm{AcOH}$. This 
data point $(\mathrm{CuL} / \mathrm{PhOH})$ confirm the trend already observed by Nocera and co-workers. However, the selectivity measured for CuL when $\mathrm{AcOH}$ is used as proton source, do not follow the same correlation, with less $\mathrm{H}_{2} \mathrm{O}$ produced $\left(59 \% \mathrm{H}_{2} \mathrm{O}\right.$ for $\triangle E^{O R R}$ of $0.490 \mathrm{~V}$ ). This behavior indicates that the overpotential requirement cannot be used as the only descriptor of the selectivity of ORR.

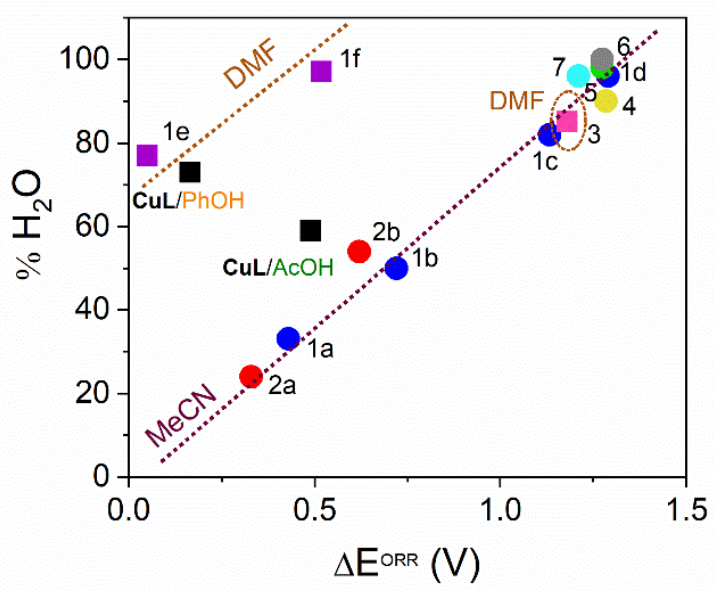

Figure 6. Faradaic efficiency for $\mathrm{H}_{2} \mathrm{O}$ production vs $\Delta E^{O R R}$ for CuL (black) in the presence of $\mathrm{PhOH}, \mathrm{AcOH}$ and TFA in DMF $\left(0.1 \mathrm{M}^{\mathrm{n}} \mathrm{Bu}_{4} \mathrm{NPF}_{6}\right)$ and comparison with other catalysts: (1) $\left[\mathrm{Co}_{2}(\mathrm{OH})_{2} \operatorname{DPEN}\left(\mu-1,3-\mathrm{OC}\left(\mathrm{NH}^{2} \mathrm{CH}_{3}\right)\right]^{3+}\right.$ (DPEN = dipyridylethane naphthyridine) in MeCN (blue) with (1a) $\mathrm{PhOH}$, (1b) $\mathrm{AcOH},(1 \mathrm{c}) \mathrm{ClCH}_{2} \mathrm{COOH}$, (1d) TFA; ${ }^{[22]}$ (1) in DMF with (purple) (1e) $\mathrm{AcOH}$, (1f) TFA; (2) $\left[\mathrm{Co}_{2}(\mathrm{OH})_{2} \mathrm{DPEN}(\mu-1,3-\mathrm{OAc})\right]^{3+}$ in $\mathrm{MeCN}$ (red) with (2a) PhOH, (2b) $\mathrm{AcOH}^{\left[{ }^{[22]}\right.}$ (3) Fe tetraphenylporphyrin in DMF with $\mathrm{HClO}_{4}$ (pink) ${ }^{[26]}$ (4) $\mathrm{Fe}$ meso-tetra(2-carboxyphenyl)porphirine in $\mathrm{MeCN}$ with $(\mathrm{HDMF})^{+}$(yellow):; ${ }^{[27]}(5)$ $\mathrm{Fe}$ meso-tetra(4-carboxyphenyl)porphirine in $\mathrm{MeCN}$ with $(\mathrm{HDMF})^{+}$(green). ${ }^{[27]}$ (6) $\mathrm{Co}^{\prime \prime \prime}{ }_{2}(\operatorname{trpy})_{2}\left(\mu \text {-bpp) }\left(\mu-1,2-\mathrm{O}_{2}\right)\right]^{3+}$ (bpp $=$ bis-(pyridyl)-pyrazolate, trpy $=$ terpyridine) in MeCN with TFA (gray):; ${ }^{[28]}(7)\left[\mathrm{Fe}_{2}{ }_{2}(\mathrm{LS})(\mathrm{LSH})\right]\left(\mathrm{LS}^{2-}=2,2^{\prime}-\left(2,2^{\prime}-\right.\right.$ bipyridine-6,6'-diyl)bis-(1,1-diphenylethanethiolate) in MeCN with lutidinium. ${ }^{[29]}$ Data measured in $\mathrm{CH}_{3} \mathrm{CN}$ are indicated as dots while data obtained in DMF are shown as squares. Dotted lines are just guides for the eye to indicate the free energy linear correclations in both solvents [Adapted with permission from ref. 22 Copyright (2016) American Chemical Society].

\section{Conclusion}

Despite their relevance as bioinspired $\mathrm{O}_{2}$-reduction catalysts, quite few studies are available for homogeneous coper-based molecular complex as ORR catalysts. We provide here one example of such an active mononuclear copper catalyst, copper(II) thiosemicarbazone complex (CuL) that displays interesting selectivity for the 4-electron reduction of oxygen to water. Our data partially confirm the previously established free energy linear correlation between selectivity and overpotential requirement. Interestingly, under certain conditions, the correlation was not observed, indicating that other descriptors have to be taken into account to design selective catalyst for the 4-electron reduction of $\mathrm{O}_{2}$. Future work will aim at understanding the catalytic mechanism and establishing structure-function relationships able to rationalize such a design.

\section{Experimental Section}

Materials and Reagents

Synthetic starting precursors, solvents, tetrabutylammonium hexafluorophosphate $\left({ }_{n} \mathrm{Bu}_{4} \mathrm{NPF}_{6}\right)$ supporting electrolyte and all other chemicals agents were purchased from Sigma Aldrich. All chemical reagents were of analytical grade and were used as received without further purification. The synthesis of the $\mathrm{H}_{2} \mathrm{~L}$ ligand was performed according to previously described procedures. ${ }^{[17]}$ Oxygen gas (Air Products ultrapure quality) was $99.995 \%$ purity.

\section{Physical and chemical characterization}

Elemental analysis was performed on a Thermo Finnigan EA 1112 instrument. The results were validated by at least two sets of measurements. IR spectra were recorded with a Bruker TENSOR 27 spectrometer equipped with a single-reflection DuraSamplIR diamond. Electronic absorption spectra were recorded with Hitachi U3310 and Perkin Elmer's LAMBDA 25 UV-Vis systems instruments controlled with UV Solutions or UV WinLab utilities, respectively.

\section{Synthesis of CuL complex}

A solution of $\mathrm{Cu}\left(\mathrm{NO}_{3}\right) \cdot 4 \mathrm{H}_{2} \mathrm{O}(0.058 \mathrm{~g}, 0.225 \mathrm{mmol})$ in methanol $(2 \mathrm{~mL})$ was added dropwise to a suspension of the 4 - $\{b i s(4-(p-m e t h o x y p h e n y l)$ thiosemicarbazone)\}-2,3-butane $\left(\mathrm{H}_{2} \mathrm{~L}\right)$ ligand $(0.1 \mathrm{~g}, 0.225 \mathrm{mmol})$ in methanol $(5 \mathrm{~mL})$. The mixture was stirred at reflux for $2 \mathrm{~h}$. The resulting red precipitate was collected by filtration, washed with methanol and dried in the air (80 mg, yield: $70 \%)$. elemental analysis calc. (\%) for $\mathrm{C}_{20} \mathrm{H}_{24} \mathrm{~N}_{6} \mathrm{O}_{2} \mathrm{~S}_{2} \mathrm{Cu}\left(506.11 \mathrm{~g} \cdot \mathrm{mol}^{-1}\right)$ : C 47.43, H 4.34, N 16.58, S 12.64; found: C 47.36, H 4.07, N 16.59, S 12.27. FT-IR (ATR): $\bar{v}=3292(\mathrm{~N}-\mathrm{H})$, $1598(\mathrm{C}=\mathrm{N}$ imine $), 1508(\mathrm{~N}-\mathrm{C}), 1240$ and $1029(\mathrm{O}-\mathrm{C}), 1176$ and 821 (C-S) $\mathrm{cm}^{-1}$

\section{Crystallographic characterization}

Diffraction data were collected using an Oxford Diffraction XCallibur $S$ Kappa area detector four-circle diffractometer (Mo-Ka radiation $\lambda=$ $0.71073 \AA$, graphite monochromator), controlled by the Oxford Diffraction CrysAlis CCD software. Unique intensities with $I>10 \sigma$ (I) detected on all frames using the Oxford Diffraction RED were used to refine the values of the cell parameters. The substantial redundancy in data allows analytical absorption corrections to be applied using crystal shape determination for CuL complex. The space group was determined from systematic absences, and it was confirmed by the successful resolution of the structure. The structure was solved by charge flipping method using ShelXS in Olex1.2 environment. All the atoms were found by difference Fourier syntheses. All non-hydrogen atoms were anisotropically refined on F2 using ShelXL program. Hydrogen atoms were fixed in ideal positions for complex and found by fourier transformation and refined isotropically.

Crystals of CuL suitable for X-ray diffraction analysis were obtained by slow evaporation of a THF solution. The CuL complex crystallizes in the monoclinic system with $\mathrm{P} 2 / 1 \mathrm{n}$ space group (Table S1). The crystal consists of a neutral mononuclear [CuL] unit and THF as solvent molecules in 1:1 ratio. The asymmetric unit consists of a neutral mononuclear CuL unit and $1 \mathrm{THF}$ solvent molecule in general positions. Crystallographic data for [CuL].THF (CCDC-1548059) can be obtained free of charge from The Cambridge Crystallographic Data Centre via: www.ccdc.cam.ac.uk/data_request/cif.

\section{Electrochemical measurements}

Electrochemical measurements were carried out with a SP-300 Bio-Logic bipotentiostat in a conventional three-electrode cell, using a stationary glassy carbon (GC) disk (ø $1.6 \mathrm{~mm}$ ) working electrode, a platinum wire as counter electrode and a $\mathrm{Ag} / \mathrm{AgCl}, \mathrm{KCl}(3 \mathrm{M})$ (denoted below $\mathrm{Ag} / \mathrm{AgCl}$ ) as the reference electrode. This $\mathrm{Ag} / \mathrm{AgCl}$ reference electrode was calibrated with the internal $\mathrm{Fc}^{+/ 0}$ reference system after each experiment, which was found at $+0.55 \mathrm{~V}$ vs Ag/AgCl. The $\mathrm{Fc}^{+/ 0}$ couple $\left(\mathrm{E}^{0}\right.$ for $\mathrm{Fc}^{+/ 0}=$ $0.57 \mathrm{~V} v s \mathrm{NHE}$, taking into account interliquid junction potential) ${ }^{[30-32]}$ was 
further used to convert potentials vs. NHE. The working electrode was polished before each measurement on a MD-Nap polishing pad with a 1 $\mu \mathrm{m}$ monocrystalline diamond paste, rinsed with ethanol and dried under air.

Cyclic voltammograms were recorded at a scan rate of $100 \mathrm{mV} \cdot \mathrm{s}^{-1}$ in $\mathrm{N}, \mathrm{N}$-dimethylformamide (DMF) with ${ }^{\mathrm{n}} \mathrm{Bu}_{4} \mathrm{NPF}_{6}(0.1 \quad \mathrm{M})$ supporting electrolyte at room temperature, under argon or oxygen atmosphere. The $1 \mathrm{M}$ solutions of phenol $(\mathrm{PhOH})$, acetic acid $(\mathrm{AcOH})$ and trifluoroacetic acid (TFA) in DMF were added with a microsyringe. Spectroelectrochemical experiments were performed in Thin Layer Quartz Glass Spectroelectrochemical cell Kit (Bio-Logic) using a platinum grid as working electrode, a platinum wire as counter electrode and a $\mathrm{Ag} / \mathrm{AgCl}$ reference electrode.

The catalytic activity of the CuL complex towards the ORR was investigated using the rotating ring-disk electrode (RRDE) technique. Pine RRDE setup with a glassy carbon disk (ø $\left.5 \mathrm{~mm}, 0.196 \mathrm{~cm}^{2}\right)$ and a Pt ring $\left(0.110 \mathrm{~cm}^{2}\right)$ was used as working electrode. RRDE experiments were carried out under $\mathrm{O}_{2}$-saturated solution. Polarization curves were recorded at $10 \mathrm{mV} \cdot \mathrm{s}-1$, with different rotation speeds. The potential of the $\mathrm{Pt}$ ring was set at $1.07 \mathrm{~V}$ vs NHE. The faradaic efficiency for $\mathrm{H}_{2} \mathrm{O}_{2}$ production as a function of potential applied at the disk is obtained according with equation (1): ${ }^{[33]}$

$\% H_{2} O_{2}=\frac{2 I_{r}(E) / N}{I_{d}(E)+I_{r}(E) / N} \times 100$

where $I_{r}(E)$ and $I_{d}(E)$ are the absolute values of ring and disk current at potential $E$ and $N$ is the collection efficiency of the electrode. The value of $\mathrm{N}$ was determined to be 0.221 using the one-electron $\left[\mathrm{Fe}(\mathrm{CN})_{6}\right]^{3-/ 4-}$ redox couple.

\section{Theoretical calculations}

Density-functional theory (DFT) calculations were performed with the ORCA program package. ${ }^{[34]}$ Full geometry optimizations were undertaken for all complexes using the GGA functional BP86 ${ }^{[35-37]}$ in combination with the TZV/P basis ${ }^{[38]}$ set for all atoms, and by taking advantage of the resolution of the identity (RI) approximation in the SplitRI-J variant ${ }^{[39]}$ with the appropriate Coulomb fitting sets. ${ }^{[40]}$ Increased integration grids (Grid4 in ORCA convention) and tight SCF convergence criteria were used. Electronic structures and Molecular Orbital diagrams were obtained from single-point calculations using the hybrid functional $B 3 L Y P^{[41-42]}$ together with the TZV/P basis set. Increased integration grids (Grid4 and GridX4 in ORCA convention) and tight SCF convergence criteria were used in the calculations. For according to the experimental conditions solvent effects were accounted and we used the DMF solvent $(\varepsilon=37)$ within the framework of the conductor-like screening (COSMO) dielectric continuum approach. ${ }^{[4]}$ The relative energies were computed from the gas-phase optimized structures as a sum of electronic energy, solvation and thermal corrections to the free energy. Redox potentials were evaluated by employing a Born-Haber thermodynamic cycle following the same procedure that was previously employed for the characterization of our cobalt analogue (see Supplementary Information for details). Spin density plots as well as molecular orbitals were generated using the orca plot utility program and were visualized with the Chemcraft program. ${ }^{[44]}$

\section{Acknowledgements}

This work was supported by the Agence Nationale de la Recherche (Labex ARCANE, CBH-EUR-GS, ANR-17-EURE0003).

Keywords: bioinspired chemistry $\cdot$ oxygen reduction reaction $•$ electrocatalysis $\bullet$ hydrogen peroxide $\bullet$ free energy linear correlation

\section{References}

[1] R. B. Gordon, M. Bertram, T. E. Graedel, Proc. Natl. Acad. Sci. U. S. A 2006, 103, 1209-1214.

[2] S. Ferguson-Miller, G. T. Babcock, Chem. Rev. 1996, 96, 2889-2908.

[3] M. M. Pereira, M. Santana, M. Teixeira, Biochim. Biophys. Acta 2001, 1505, 185-208.

[4] E. Vayner, H. Schweiger, A. B. Anderson, J. Electroanal. Chem. 2007 607, 90-100.

[5] E. I. Solomon, U. M. Sundaram, T. E. Machonkin, Chem. Rev. 1996, 96, 2563-2606.

[6] Z. Halime, H. Kotani, Y. Li, S. Fukuzumi, K. D. Karlin, Proc. Natl. Acad Sci. U. S. A. 2011, 108, 13990-13994.

[7] J. P. Collman, R. Boulatov, Angew. Chem. Int. Ed. 2002, 41, 3487 3489 .

[8] S. Kakuda, R. L. Peterson, K. Ohkubo, K. D. Karlin, S. Fukuzumi, J. Am. Chem. Soc. 2013, 135, 6513-6522.

[9] J. Zhang, F. C. Anson, J. Electroanal. Chem. 1992, 341, 323-341.

[10] Yabin Lei, F. C. Anson, Inorg. Chem. 1994, 33, 5003-5009.

[11] M. S. Thorum, J. Yadav, A. A. Gewirth, Angew. Chem. Int. Ed. 2009 48, 165-167.

[12] C. C. McCrory, A. Devadoss, X. Ottenwaelder, R. D. Lowe, T. D. Stack, C. E. Chidsey, J. Am. Chem. Soc. 2011, 133, 3696-3699.

[13] S. Gentil, D. Serre, C. Philouze, M. Holzinger, F. Thomas, A. Le Goff, Angew. Chem. Int. Ed. 2016, 55, 2517-2520.

[14] F. R. Brushett, M. S. Thorum, N. S. Lioutas, M. S. Naughton, C. Tornow, H. R. Jhong, A. A. Gewirth, P. J. A. Kenis, J. Am. Chem. Soc 2010, 132, 12185-12187.

[15] M. A. Thorseth, C. E. Tornow, E. C. M. Tse, A. A. Gewirth, Coord. Chem. Rev. 2013, 257, 130-139.

[16] M. A. Thorseth, C. S. Letko, T. B. Rauchfuss, A. A. Gewirth, Inorg Chem. 2011, 50, 6158-6162.

[17] T. Straistari, J. Fize, S. Shova, M. Réglier, V. Artero, M. Orio, ChemCatChem 2017, 9, 2262-2268.

[18] A. A. Abou-Hussen, N. M. El-Metwally, E. M. Saad, A. A. El-Asmy, J. Coord. Chem. 2005, 58, 1735-1749.

[19] M. B. Ferrari, G.G. Fava, C. Pelizzi, G. Pelosi, P. Tarasconi, Inorg Chem. Acta 1998, 269, 297-301.

[20] K. Izutsu, Wiley-Blackwell, 1990

[21] C. P. Andrieux, J. Gamby, P. Hapiot, J.-M. Saveant, J. Am. Chem. Soc 2003, 125, 10119-10124.

[22] G. Passard, A. M. Ullman, C. N. Brodsky, D. G. Nocera, J. Am. Chem. Soc. 2016, 138, 2925-2928.

[23] C. Costentin, T. R. Porter, J. M. Saveant, J. Am. Chem. Soc. 2016, 138, 5615-5622.

[24] C. Costentin, S. Drouet, M. Robert, J. M. Saveant, J. Am. Chem. Soc 2012, 134, 11235-11242.

[25] V. Artero, J. M. Saveant, Energy Environ. Sci. 2014, 7, 3808-3814.

[26] D. J. Wasylenko, C. Rodriguez, M. L. Pegis, J. M. Mayer, J. Am. Chem. Soc. 2014, 136, 12544-12547.

[27] C. T. Carver, B. D. Matson, J. M. Mayer, J. Am. Chem. Soc. 2012, 134, 5444-5447.

[28] S. Fukuzumi, S. Mandal, K. Mase, K. Ohkubo, H. Park, J. BenetBuchholz, W. Nam, A. Llobet, J. Am. Chem. Soc. 2012, 134, 99069909

[29] L. Wang, M. Gennari, F. G. Cantu Reinhard, J. Gutierrez, A. Morozan, C. Philouze, S. Demeshko, V. Artero, F. Meyer, S. P. de Visser, C Duboc, J. Am. Chem. Soc. 2019, 141, 8244-8253.

[30] S. D. Cyrille Costentin, Marc Robert, Jean-Michel Savéant, Science 2012, 338, 90-94.

[31] T. N. Huan, E. S. Andreiadis, J. Heidkamp, P. Simon, E. Derat, S Cobo, G. Royal, A. Bergmann, P. Strasser, H. Dau, V. Artero, M. Fontecave, J. Mater. Chem. A 2015, 3, 3901-3907.

[32] T. N. Huan, P. Simon, G. Rousse, I. Genois, V. Artero, M. Fontecave Chem. Sci. 2017, 8, 742-747.

[33] X. Wei, Y. Geping, Z. Jiujun, Rotating Electrode Methods and Oxygen Reduction Electrocatalysts, 2014

[34] F. Neese, Rev. Comput. Mol. Sci. 2012, 2, 73-78.

[35] J. P. Perdew, Phys. Rev. B 1986, 33, 8822-8824.

[36] J. P. Perdew, Phys. Rev. B 1986, 34, 7406-7406.

[37] A. D. Becke, Phys. Rev. A 1988, 3098-3100.

[38] A. Schafer, C. Huber, R. Ahlrichs, J. Chem. Phys. 1994, 100, 58295835. 
[39] F. Neese, J. Comput. Chem. 2003, 24, 1740-1747.

[40] F. Weigend, Phys. Chem. Chem. Phys. 2006, 8, 1057-1068.

[41] A. D. Becke, J. Chem. Phys. 1993, 98, 1372-1377.

[42] C. Lee, W. Yang, R. G. Parr, Phys. Rev. B 1988, 37, 785-789.

[43] A. Klamt, G. Schuurmann, J. Chem. Soc., Perkin Trans. 2 1993, 799805.

[44] C. Chemcraft, http://chemcraftprog.com 


\section{Entry for the Table of Contents}

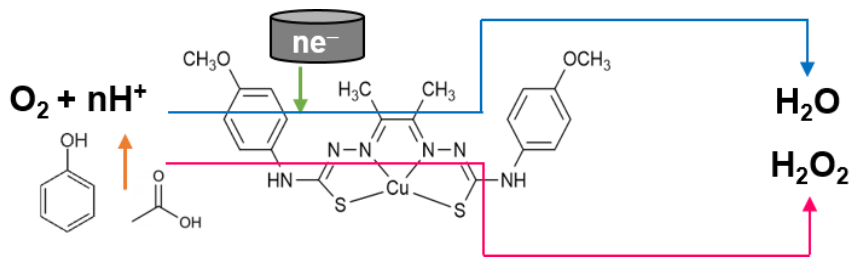

The mononuclear, copper(II) thiosemicarbazone complex (CuL) catalyzes the homogeneous oxygen reduction reaction (ORR) via a combined $4 \mathrm{H}^{+} / 4 \mathrm{e}^{-}$and $2 \mathrm{H}^{+} / 2 \mathrm{e}^{-}$process in the presence of various organic acids as proton sources. 